\title{
A Comparison of Antimetastatic Activity between Nerium indicum and Cinnamomum burmannii on 4TI Cells
}

\author{
Beni Lestari $^{1}$, Laeli Muntafiah ${ }^{1}$, Ziana Walidah $^{1}$, Riris Istighfari Jenie ${ }^{1,2^{*}}$ \\ ${ }^{1}$ Cancer Chemoprevention Research Center, Faculty of Pharmacy, Universitas Gadjah Mada, Indonesia \\ ${ }^{2}$ Department of Pharmaceutical Chemistry, Faculty of Pharmacy, Universitas Gadjah Mada, Indonesia
}

\begin{abstract}
Metastatic process becomes a major problem in advanced cancer cases. Natural compounds found in several plants in Indonesia have a potency to be developed as chemoterapeutic agent which are targeted to metastatic process. Jure leaves (Nerium indicum) which contain oleandrin and cinnamaldehyde in cinnamon bark (Cinnamomum burmannii) reported to have cytotoxic activity on several cancer cells, but their activities on metastasic process have never been explored. This research aims to reveal and to compare their anti-metastatic effect toward 4TI breast cancer cells. The cytotoxicity of jure leaves extract (JLE) and cinnamon essential oil (CEO) was obtained by MTT assay. Metastatic process mainly on cell migration was examined by scratch wound healing assay while MMP-9 expression that described the invassion process was observed by gelatin zymography assay. Molecular interaction between their active compounds and MMP-9 receptor was predicted by molecular docking. The result showed that treatment with JLE and CEO inhibited the growth of 4TI cells with IC 50 value of $125 \mu \mathrm{g} / \mathrm{mL}$ and $2.5 \mu \mathrm{g} / \mathrm{mL}$, respectively. In addition, JLE performed inhibitory effect of cell migration better than CEO. Meanwhile, both JLE and CEO decreased MMP-9 protein expression. Thus, JLE and CEO have potentials to be developed as an anti-metastatic agent and JLE could be more effective.
\end{abstract}

Keywords: Nerium indicum, Cinnamomum burmannii, anti-metastasis, scratch assay, gelatin zimography

\section{INTRODUCTION}

Cancer remains a major burden of disease worldwide. Cancer can be categorized as a "silent killer" disease due to the death of cancer patients that was suffering from cancer at advanced stage (metastasis) and lack of success in the early detection. This data is also supported by the WHO (2009) which states that metastasis is the leading cause of cancer-associated mortality. Therefore, various strategies should be continuously developed to inhibit cancer cells migration, especially from natural compounds.

Natural materials of Indonesia were reported to have anti-cancer activity are jure leaves (Nerium indicum) and cinnamon (Cinnamomum burmannii) which containing oleandrin and cinnamaldehyde as the major compounds (Manna, et al, 2000; Siddiqui, et al, 1987; Hembing, 1993). Nerium indicum is one such plant which is famed for its therapeutic efficiency for various species. Jure leaves have been reported as anti-cancer agent since 1980 (Hartwel, 1982), cardiac illnesses, asthma, corns, cancer, and epilepsy (Duke and Boca Raton, 1985) hypertension and also diabetes (Tahraoui, 2007). On the other hand, Cinnamon is potential to be developed as chemopreventive agent because it can be inhibitor of angiogenesis protein (Lu, et al., 2010). It also inhibits many cancer cells growth and induces $\mathrm{G} 2 / \mathrm{M}$ phase arrest (Scoene, et al., 2008). Scientific research regarding anti-metastatic of these plants has never been done.

Therefore, this study aims to to reveal and to compare their anti-metastatic effect toward 4T1 breast cancer metastatic cells. This study comprehensively examines the anti-metastatic ability of jure leaves extract (JLE) and cinnamomum essential oil (CEO). Anti-metastatic activity was observed through two parameters: the cell migration by scratch wound healing assay and MMP-9 protein expression of by gelatin zymography method. Molecular interactions between the active compound contained in JLE and CEO against MT1-MMP as activator protein MMP which is seen through the molecular docking.

$\overline{* \text { Corresponding author e-mail: riris_jenie@ugm.ac.id }}$ 


\section{MATERIALS AND METHODS}

\section{Cell Culture}

4T1 breast cancer cells were obtained from Prof. Masashi Kawaichi (Nara Institute of Science and Technology, NAIST, Japan). The cells were maintained in Dulbecco's Modifies Eagles medium (DMEM) high glucose (Sigma) with 10\% FBS (Sigma), HEPES, sodium bicarbonate, $1.5 \%$ Penicilin-Streptomycin and $0.5 \%$ Fungizone (Gibco).

\section{Sample Preparation}

Jure leaves are obtained from Faculty of Pharmacy, Universitas Gadjah Mada, Yogyakarta. Jure leaves are being dried and extracted by soxhlet with petroleum ether and ethanol $96 \%$ respectively. The filtrate is being concentrated by rotary vacuum evaporator. Cinnamons are obtained from Boyolali, Central Java. Cinnamons are being dried and cut off into small pieces. Cinnamon were extracted by distillate.

\section{Cytotoxic Test}

Cytotoxic test by MTT is being used to know JLE and CEO cytotoxicity to 4T1 cells. 4T1 cells were seeded in 96-well plate with $5 \times 10^{3}$ cells/well and were incubated in 24 hours. Cells treated with increasing concertations of JLE $(10,50,100,250$, $500 \mu \mathrm{g} / \mathrm{mL})$ and CEO $(0.2,1,2,3,4,5 \mu \mathrm{g} / \mathrm{mL})$ for 24 hours. Media were removed and washed with 100 $\mu$ I PBS (Sigma), add MTT reagen with contration 5 $\mathrm{mg} / \mathrm{mL}$ to each wells the incubate in $37^{\circ} \mathrm{C}$ for 4 hours. The living cells can change MTT reagen into purple-colored formazan. After incubating add stopper reagent SDS $10 \% \mathrm{HCl} \quad 0.01 \quad \mathrm{~N}$ and incubating over night. Shake the plate in 10 minutes and read the absorbance with ELISA reader at $\lambda 595$ $\mathrm{nm}$ (Biorad). The single absorbance data converted into viability percent and will be used to measure $\mathrm{IC}_{50}$.

\section{Scratch Wound Healing Assay}

Scratch wound healing assay is method to measures the expansion of a cell population on surfaces. $4 \mathrm{~T} 1$ cells planted $7.5 \times 10^{4}$ cells/well in $24-$ wellplate. Cells incubated for 24h until $80 \%$ confluen. Media were removed and washed with 100 $\mu \mathrm{L}$ PBS (Sigma), added media culture with $0.5 \%$
FBS for stravation step and incubated for 24 hours. Scratch vertically in each base of the wells using the tip of yellow tip and treated with JLE and CEO. Observed in $0,18,24$ and 42 hours under inverted microscope and capture it with camera. Scratch analysis done by measure the migration distance using ImageJ software by comparing the distance between untreated and treatment.

\section{Gelatin Zymography Assay}

This method is for observing enzymatic activity of MMP-9 in 4T1 cells. Medium starvation with concentration of JLE and CEO were collected and become a sample of gelatin zymography. Electrophoresis used 8\% SDS-PAGE that contains $0.1 \%$ gelatin. After running gel washed with $100 \mathrm{~mL}$ aquadest that contains $2 \%$ Triton $\mathrm{X}-10$ in 30 minutes so that the SDS can disappear, gel incubated in 100 $\mathrm{mL}$ buffer reaction $(40 \mathrm{mM}$ Tris- $\mathrm{HCl} \mathrm{pH} 8,10 \mathrm{nM}$ $\mathrm{CaCl}_{2}, 0.02 \% \mathrm{NaN} 3$ ) for 20 hours in $37^{\circ} \mathrm{C}$, gel was painted with Coomassie Briliant blue R-250 and destined with destining solution (20\% methanol, $10 \%$ acetate acid, and $70 \%$ water) (Hsieh, et al., 2013). Gelatin degradation by MMP-9 activity observed by the appearance of transparent tape in gel. Next, the intensity of transparent tape analyzed with imageJ software.

\section{Molecular Docking Analysis}

The 3D structure of tested compounds, oleandrin and cinnamaldehyde made by MarvinSketch software. The structure of target protein, MMP-2 (PDB ID: 1HOV) and MMP-9 (PDB ID: 2OVX) were downloaded from PDB and the preparation done by YASARA software. Docking validation was performed by ProteinLigand Ant System (PLANTS) 1.1 manual program. Visualization 2D and 3D performed by MOE 2010 software (Licensed by Faculty of Pharmacy, Universitas Gadjah Mada).

\section{RESULT}

\section{Cytotoxic effect of JLE and CEO on 4TI cells}

The cytotoxic effects of JLE and CEO are detected by MTT Assay with $\mathrm{IC}_{50}$ value as the parameter, the low $\mathrm{IC}_{50}$ value indicates potential cytotoxicity. $\mathrm{IC}_{50}$ values on JLE and CEO are 125 $\mu \mathrm{g} / \mathrm{mL}$ and $2.5 \mu \mathrm{g} / \mathrm{mL}$ on $4 \mathrm{~T} 1$ cells (Fig. 1). 

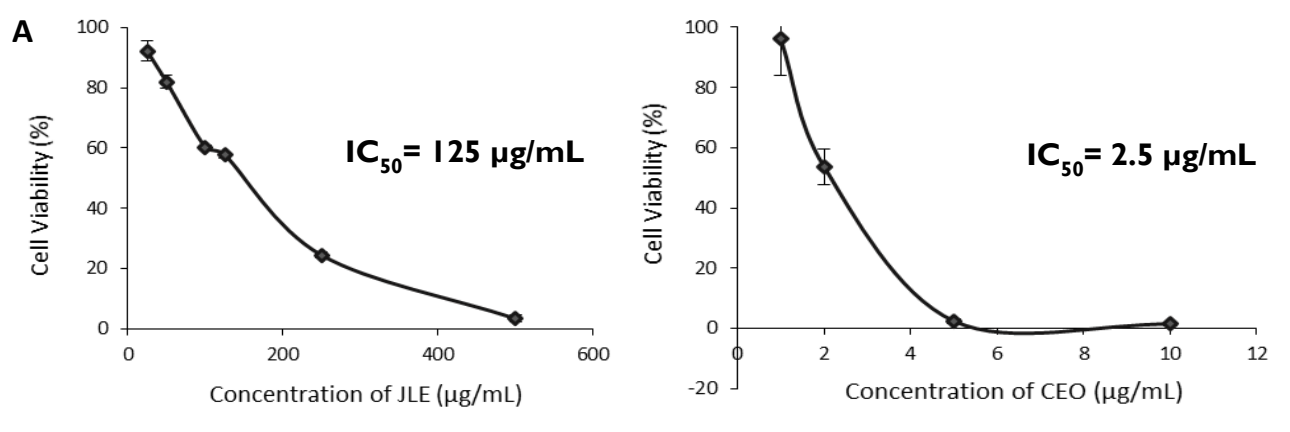

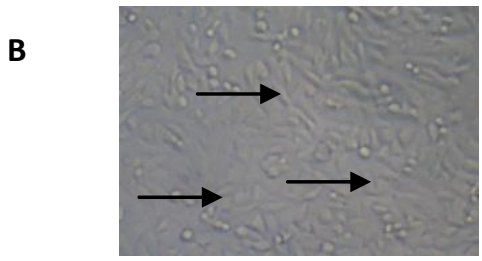

Untreated

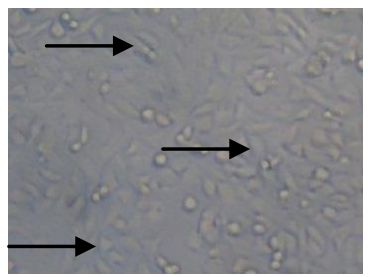

Untreated

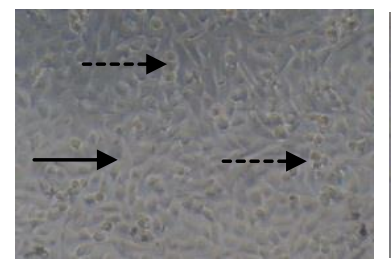

JLE $50 \mu \mathrm{g} / \mathrm{mL}$

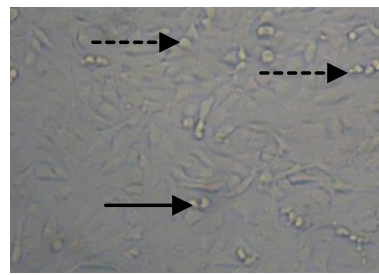

CEO I $\mu g / m L$

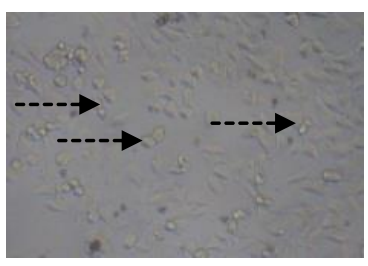

JLE I $25 \mu g / m L$

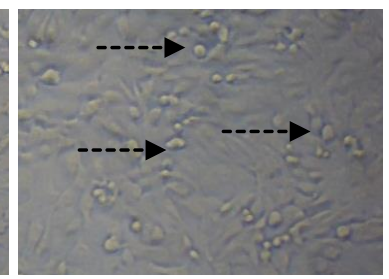

CEO $2 \mu \mathrm{g} / \mathrm{mL}$

Figure I. Cytotoxic effect of JLE and CEO on 4TI cells. 4TI cells (IxI04 cells/well) were treated with JLE and CEO in the concentration as indicated in the picture, then subjected for MTT assay. The IC 50 value performed triplicate and was calculated by using linear regression in three independent experiments. (A) The cell viability profile showed at various concentrations of JLE, CEO, and the combination ( $N=6 ; p<0.0$ I for JLE and $N=4 ; p<0.05$ for CEO). (B) Morphology of 4TI cells after treatment JLE and CEO.

Based on Prayong, et al. (2008), an $\mathrm{IC}_{50}$ value below $100 \mu \mathrm{g} / \mathrm{mL}$ indicates a potent cytotoxic effect whereas over $100 \mu \mathrm{g} / \mathrm{mL}$ indicates moderate cytotoxicity. Accordingly, CEO has potential $\mathrm{IC}_{50}$ cytotoxic value whereas JLE has $\mathrm{IC}_{50}$ value with moderate cytotoxic category. CEO performed stronger cytotoxic effect than JLE on $4 \mathrm{~T} 1$ cells.

\section{Antimigration effect of JLE and CEO on 4TI cells}

The inhibitory ability of 4T1 cell migration by JLE and CEO is measured by looking at the closing space inhibition of scratch performed (\% closure) in the wound healing assay method. 4T1 cell be used for a model in scratch assay because it is one kind of breast cancer cells that have an ability to do metastasis with parameter \% closure. Statistical analysis using SPSS (n:3; $p<0.005$ ) showed that treatments of JLE and CEO tended to decrease the width of scratch which was due to cell migration compared to untreated (Fig. 2). Accordingly, JLE has potential as a metastatic agent by inhibiting cell migration higher than CEO.

\section{Inhibition of MMP-9 protein using gelatin zymography assay}

Besides migration cell, metastasis process of cell affected by the MMP-9 and MMP-2 expression and activity. From this result, it can be seen that there is gelatinase activity of MMP-9, but the gelatinase activity of MMP-2 can't be seen. Its because 4T1 not expression MMP-2 enzyme. Fig. 3 showed that JLE and CEO have potentioals to be developed as chemoprevention and anti-metastasis agent for advanced stage cancer therapy by decrease expression of MMP-9 protein expression. 
A

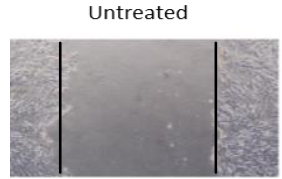

18

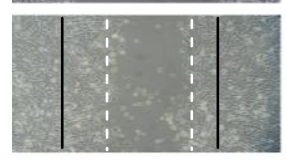

24

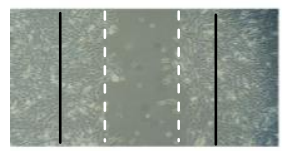

42

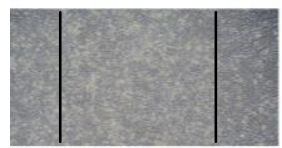

JLE
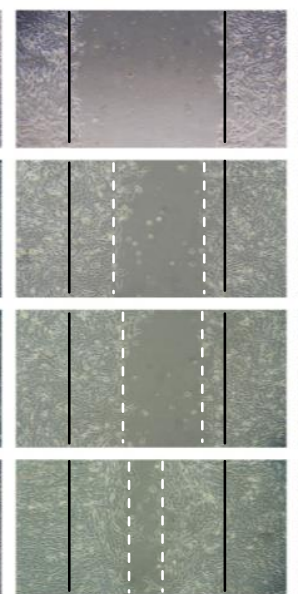

CEO

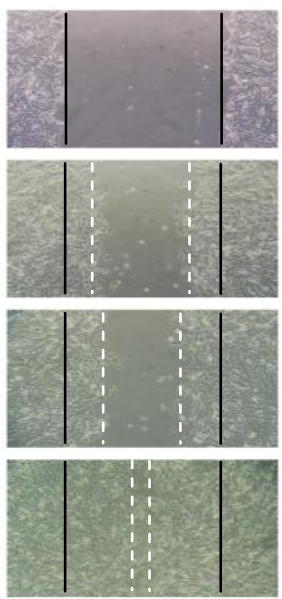

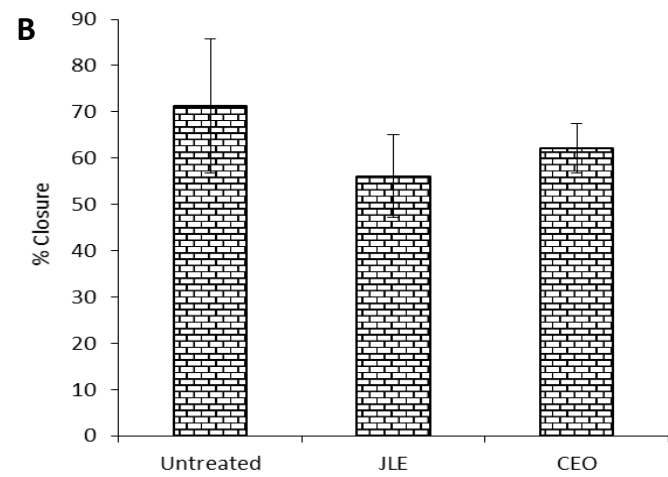

Figure 2. Effect of Single Treatment of JLE and CEO on 4T I Cells Migration. (A) The morphology of the cells after scratch and treated with JLE and CEO. Observations were made after 18, 24 and 42 hour of treatment under an inverted microscope with magnification of 100x. (B) The percentage of 4TI cells closure after treatment. The area of the scratch were analyzed using Imagej software then \% closure was calculated in accordance with the procedures of the analysis.

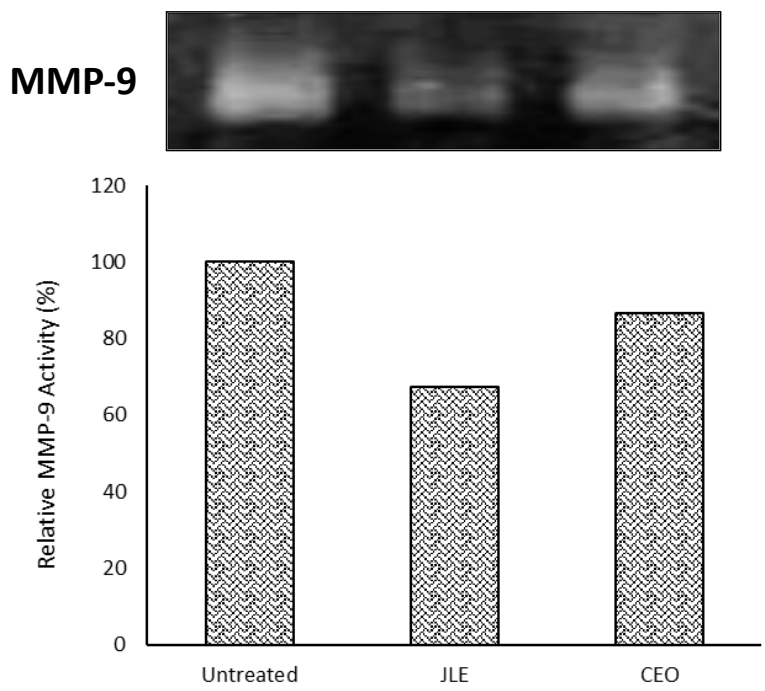

Figure 3. Effect of Single Treatment of JLE and CEO in MMP-9 Expression on 4TI Cells. Cells were treated with JLE and CEO. MMP-9 activity assay was conducted using gelatin zymography according to the method. Analysis of the results were done by using Imagej software to measure the intensity of gelatin degradation by MMP-9 in the gel.

\section{Molecular docking Result}

Molecular docking is one of in silico test to predict the interaction ability between ligan native (active molecul) with receptor. In this reserch, molecular docking use to know interaction ability between oleandrin (active molekul in JLE) and cinnamaldehyde (active molecul in CEO) with MMP-2 and MMP-9 receptor. That interaction is visualized and determinated by amino acid residue which interacting between oleandrin and cinnamaldehyde ligand against MMP-2 and MMP-9. Molecular docking analyzation based on score docking that represent the needed energy for bounding. The smaller the docking score, the bound between compound and ligand get stronger. The score docking ligand compound in estrogen receptor can be seen in Table 1 and the visualization can be seen in Fig. 4.

From the molecular docking result obtained oleandrin and cinnamaldehyde score docking in MMP-2 are -88,2025 and -67,1808. Meanwhile, oleandrin and cinnamaldehyde score docking in MMP-9 are -78,9117 and -68,0184. Therefore, oleandrin and cinnamaldehyde compunds have lower score docking compared to native ligand which signed the compound bound's strength with ligand is not as strong as native ligand. 
Table I. Docking scores of oleandrin and cynnamaldehyde on MMP-2 and MMP-9

\begin{tabular}{lll}
\hline \multirow{2}{*}{ Ligand } & \multicolumn{2}{c}{ Docking score (kKal/mol) } \\
\cline { 2 - 3 } & MMP-2 & MMP-9 \\
\hline Native Ligand & -130.558 & -110.992 \\
Oleandrin & -88.2025 & -78.9117 \\
Cinnamaldehyde & -67.1808 & -68.0184 \\
\hline RMSD & $2.3047 \circ \mathrm{A}$ & $1.8543 \circ \mathrm{A}$ \\
\hline
\end{tabular}

MMP-2

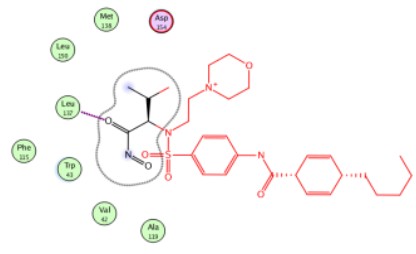

MMP-9

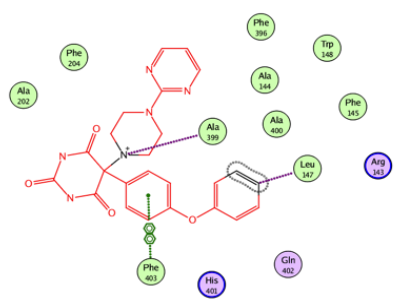

Oleandrin
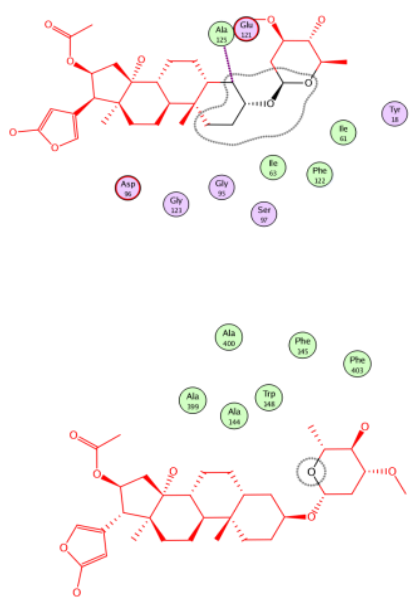

Cinnamaldehyde

Figure 4. Interaction of oleandrin and cinnamaldehyde on MMP-2 and MMP-9. Visualization of 2D ligand interaction on MMP-2 and MMP-9 receptor. These molecular Interaction was performed by using MOE software. The sign showed the same amino acid residues at the site of connective.

\section{DISCUSSION}

Metastasis is the major cause of death from cancer. It was found that the patients were aware when the cancer spread into various organs. Thus, it is necessary to develop anti-metastatic agent from natural compounds. The main purpose of this study is to explore and to compare the potential metastaticinhibitor of JLE and CEO on 4T1 cells. 4T1 cells were used as the model of human metastatic breast cancer cells (Heppner, et al. 2000).

Identification of the containing compounds of JLE and CEO under chromatography analysis showed that JLE contains oleandrin and CEO contains cinnamaldehyde as the major compounds. It has been reported that JLE contained many cardenolide compounds such as oleandrin, oleandrigenin, digoxin, digitoin, digitoxigenin, nerizosida, neritalosida, odorosida (Trease and Evans, 2002). On the other hand, under gas chromatography analysis, the result showed that the content of cinnamaldehyde in the CEO was approximately $96.40 \%$, which is higher than the previous studies by Wang, et al. (2009) and Larasati, et al. (2014) which reported $60.72 \%$ and $89.40 \%$, respectively. The presence of oleandrin in JLE and cinnamaldehyde in CEO might be responsible for cytotoxic activity of both compounds.

This study demonstrated the potency of JLE and $\mathrm{CEO}$ as an anti-cancer agent which has the potency of inhibiting $4 \mathrm{~T} 1$ cell proliferation with $\mathrm{IC}_{50}$ values of $125 \mu \mathrm{g} / \mathrm{mL}$ and $2.5 \mu \mathrm{g} / \mathrm{mL}$, respectively. 
The presence of cytotoxic activity of JLE and CEO is reinforced with the changes of $4 \mathrm{~T} 1$ cell morphology along the increasing of the concentrations. Several studies showed that JLE also performed cytotoxic effect on leukemic cells such as HL60 and K562 (Turan, et al., 2006), and also lung cancer A549 (Jose, et al., 2013). Oleandrin as the major compound of JLE also showed cytotoxic effect on myeloma cancer cells and kidney cancer cells (Wahyuningsih, et al., 2000; Wahyuningsih, et al., 2006). The previous studies reported that oleandrin in JLE induced apoptosis in prostate cancer cells through inhibition of the $\mathrm{Na}^{+}, \mathrm{K}^{+}-$ ATPase (McConkey, et al., 2000). In other studies proved that aqueous extract of jure leaves were able to block NF- $\kappa \beta$ and AP-1 induced by TNF, PMA, and LPS (Manna, et al., 2001). Blocking NF- $\kappa$ B can cause tumor cells to stop proliferating and induce apoptosis. While cinnamaldehyde in CEO reported by Larasati, et al. (2014) on HeLa cells and Koppikar, et al. (2010) on SiHa cells, types of cervical cancer, showed that cinnamon performed cytotoxic effect with $\mathrm{IC}_{50}$ value of $250 \mu \mathrm{g} / \mathrm{mL}$ and $320 \mu \mathrm{g} / \mathrm{mL}$, respectively. Cinnamaldehyde has Antiinflammatory effect by blocking the degradation of I $\mathrm{B}$ leading to suppression of $\mathrm{NF}-\mathrm{\kappa B}$ activation (Liao, et al., 2005). Moreover, cinnamaldehyde is an inhibitor of angiogenesis as a natural VEGF inhibitor (Lu, et al., 2010). These results suggested that JLE and CEO showed higher toxicity on 4T1 metastatic breast cancer cells than on cervical cancer cells that could potentially be useful in cancer prevention and/or treatment. Further study focusing on NF- $\mathrm{BB}$ activation and expression will elucidate more detail to these phenomena.

In this present study, we also observed and compared the inhibition of cancer cell migration by single treatment of JLE and CEO through scratch wound healing assay. Cell migration is one of parts in metastasis process. Single treatment of JLE tend to inhibit 4T1 cell migration greater than the treatment of CEO solely (Fig. 2). We also explored the inhibition of cancer cell invasion by the measurement of matrix metalloproteinase-9 (MMP9) expression under gelatin zymography assay. The result in inhibitory effect of cell invasion was consistent with cell migration inhibitory which performed that JLE decreased MMP-9 expression higher than CEO.
Molecular docking assay was conducted to compare the interaction between oleandrin in JLE and cinnamaldehyde in CEO with MMP-2 and MMP-9 proteins. Molecular docking result confirmed that the affinity between oleandrin with MMP-2 and MMP-9 was lower than the affinity between cinnamaldehyde with MMP-2 and MMP-9 proteins. Moreover, when compared with cinnamaldehyde, oleandrin bond more amino acid residues in MMP-2 and MMP-9 binding site. Based on the result, we predicted that JLE was more potential as an anti-metastatic agent than CEO.

In general, it can be noted that the treatment of JLE and CEO have a tendency in inhibiting 4T1 cell migration. In this case, the cytotoxic activity of JLE and CEO did not affect the inhibitory effect of 4T1 cell migration because of the different mechanisms and does not influenced each other. It can be shown that cytotoxicity of CEO was very powerful with the lower $\mathrm{IC}_{50}$ compared to the JLE, but it did not show inhibitory effect of cell migration. These findings demonstrated that JLE exert stronger anti-metastatic activity than CEO although JLE was less cytotoxic. The mechanism underlying anti-migration effect of JLE and CEO remains to be clarified.

\section{ACKNOWLEDGEMENT}

We express our gratitude to Directorate General of Learning and Student Affairs, Ministry of Research, Technology and Higher Education for the grant research under Student Creativity Program in 2014.

\section{REFERENCES}

Duke, J.A. and Boca Raton, 1985, Handbook of Medicinal Herbs, Florida: CRC Press.

Hartwel, J.L., 1982, Plants Used Against Cancer, 407, Massachusetts: Quarterman Publication, Inc., Lawrence.

Hembing, W.H.M., 1993, Tanaman Berkhasiat Obat di Indonesia, 2nd Edition, 74-75, Jakarta: Pustaka Kartini.

Heppner, G.H., Miller, F.R. and Shekhar, P.M., 2000, Nontransgenic Models of Breast Cancer, Breast Cancer Res., 2(5), 33I-334. 
Hsieh, Y.S., Chu, S.C., Yang, S.F., Chen, P.N., Liu, Y.C. and Lu, K.H., 2007, Silibinin Suppresses Human Osteosarcoma MG-63 Cell Invasion by Inhibiting the ERK-dependentc-Jun/AP-I Induction of MMP-2, Carcinogenesis, 28, 977298.

Hu, K., Liu, Q., Wang, S. and Ding, K., 2009, New Oligosaccharides Prepared by Acid Hydrolysis of the Polysaccharides from Nerium indicum Mill and Their Antiangiogenesis Activities, Carbohydr. Res., 344(2), 198-203.

Calderón-Montaño, J.M., Burgos-Morón, E., Orta, M.L., Mateos, S. and López-Lázaro, M., 2013, A Hydroalcoholic Extract from the Leaves of Nerium oleander Inhibits Glycolysis and Induces Selective Killing of Lung Cancer Cells, Planta Med., 79(12), I0I7-1023.

Koppikar, S.J., Choudhari, A.S., Suryavanshi, S.A., Kumari, S., Chattopadhyay, S. and KaulGhanekar, R., 2010, Aqueous Cinnamon Extract (ACE-c) from the Bark of Cinnamomum Cassia Causes Apoptosis in Human Cervical Cancer Cell Line $(\mathrm{SiHa})$ Through Loss of Mitochondrial Membrane Potential, BMC Cancer, 1 0, 210.

Larasati, Y. A., Putri, D. D. P., Utomo, R. Y., Hermawan, A., and Meiyanto, E., 2014, Combination of Cisplatin and Cinnamon Essential Oil Inhibits HeLa Cells Proliferation through Cell Cycle Arrest, J. App. Pharm. Sci., 4(I2), 0I4-0I9.

Liao, L.B., Zhou, H.Y. and Xiao, X.M., 2005, Spectroscopic and Viscosity Study of Doxorubicin Interaction with DNA, J. Mol. Struct., 749(I-3), 108-II3.

Lu, J., Zhang, K., Nam, S., Anderson, R., Jove, R. and Wen, W., 2010, Novel Angiogenesis Inhibitory Activity in Cinnamon Extract Blocks VEGFR2 Kinase and Downstream Signaling, Carcinogenesis, 3 I (3), 48 I-488.
McConkey, D.J., Lin, Y., Nutt, L.K., Ozel, H.Z. and Newman, R.A., 2000, Cardiac Glycosides Stimulate $\mathrm{Ca} 2+$ Increases and Apoptosis in Androgen-independent, Metastat ic Human Prostate Adenocarcinoma Cells, Cancer Res., 60(14), 3807-38I2.

Manna, S.K., Sah, N.K., Newman, R.A., Cisneros, A. and Aggarwal, B.B., 2000, Oleandrin Suppresses Activation of Nuclear Transcription Factor-KB, Activator Protein-I, and c-Jun NH2-Terminal Kinase, Cancer Res., 60(I4), $3838-3847$.

Prayong, P., Barusrux, S. and Weerapreeyakul, N., 2008, Cytotoxic Activity Screening of Some Indigenous Thai Plants, Fitoterapia, 79(7-8), 598-60I.

Scoene, N. W., Kelly, M. A., Polansky, M. M. and Anderson, R. A., 2008, A Polyphenol Mixture from Cinnamon Targets p38 MAP KinaseRegulated Signaling Pathways to Produce G2/M Arrest, J. Nutr. Biochem., 20(8), 614620.

Siddiqui, S., Hafeez, F., Begum, S. and Siddiqui, B.S., 1987, Isolation and Structure of Twocardiac Glycosides from the Leaves of Nerium oleander, Phytochemistry, 26(I), 237-24I.

Wahyuningsih, M. S. H., Wahyuono, S. and Artama, W. T., 2000, Efek Sitotoksik Oleandrin, Senyawa Bioaktif Hasil Isolasi dari daun Nerium indicum Mill. Terhadap Sel Mieloma, Berkala llmu Kedokteran, 32(4), 235-24I.

Wahyuningsih, M.S.H., 2006, Selektivitas dan Mekanisme Antikanker 5a-oleandrin dan dehidrodeasetil-5a-oleandrin Hasil Isolasi daun jure (Nerium indicum Mill.), Disertation, Universitas Gadjah Mada, Yogyakarta.

Wang, R., Wang, R. and Yang, B., 2009, Extraction of Essential Oils from Five Cinnamon Leaves and Identification of Their Volatile Compound Compositions, Innov. Food Sci. Emerg. Techno., I0(2), 289-292. 